\title{
Teachers as Embedded Practitioner-Researchers in Innovative Learning Environments
}

JoAnne Blannin ${ }^{* 1}$, Marian Mahat ${ }^{2}$, Benjamin Cleveland ${ }^{3}$, Julia E. MORRIS ${ }^{4}$ AND WesLey IMMS ${ }^{2}$

$\approx \quad$ The paper introduces and explores the Plans to Pedagogy research programme, a three-year project focused on teacher capacity-building within schools. Plans to Pedagogy engages practitioner-researchers in the development of their and their colleagues' spatial learning skills as they move into and attempt to take advantage of innovative learning environments. The programme involves teachers from eight schools across Australia and New Zealand. Still in progress, each three-year project addresses the individual school's needs, while being supported by a more extensive university-situated "umbrella" research programme. This paper presents emerging findings from Plans to Pedagogy and discusses what is being learned about applied research in schools and how a research-focused approach to professional learning can enhance teacher learning and practice.

Keywords: teacher-researchers, applied research, professional development, innovative learning environments, teacher change

$1 \quad{ }^{\star}$ Corresponding Author. Faculty of Education, Monash University, Australia; joanne.blannin@unimelb.edu.au.

2 Melbourne Graduate School of Education, University of Melbourne, Australia.

3 Faculty of Architecture, Building and Planning, University of Melbourne, Australia.

4 School of Education, Edith Cowan University, Australia. 


\section{Učitelji kot praktiki raziskovalci, vključeni v inovativna učna okolja}

Joanne Blannin, Marian Mahat, Benjamin Cleveland, Julia E. Morris in Wesley IMMS

$\approx$ Prispevek predstavlja in preiskuje raziskovalni program »Plans to Pedagogy«, triletni program, usmerjen h krepitvi učiteljske zmogljivosti v šolah. »Plans to Pedagogy« vključi praktike raziskovalce v razvoj prostorskih učnih sposobnosti pri njih samih in pri njihovih sodelavcih, $s$ tem ko se premaknejo v inovativno učno okolje in ga skušajo povsem izkoristiti. Program vključuje učitelje iz osmih šol iz Avstralije in Nove Zelandije. Čeprav še vedno v teku vsak triletni projekt naslavlja potrebe posamezne šole, pri čemer ga podpira obsežnejši, univerzitetno lociran osrednji raziskovalni program. Prispevek prikazuje nastajajoče ugotovitve, ki izhajajo iz »Plans to Pedagogy«, in razpravlja o tem, kaj se uči o aplikativnih raziskavah $\mathrm{v}$ šolah ter kako lahko raziskovalno usmerjen pristop k strokovnemu učenju izboljša izobraževanje in prakso učiteljev.

Ključne besede: učitelji raziskovalci, aplikativna raziskava, strokovni razvoj, inovativno učno okolje, učiteljeva sprememba 


\section{Introduction and Context}

The term innovative learning environments, or ILEs, is increasingly used to describe a school facility design that is characterised by highly flexible spaces, purposeful furniture and other learning space affordances, alongside ubiquitous technology. However, it is a term that also implies a corresponding innovative use of those spaces, via improved pedagogy and student-centred learning. The latter, sometimes described as "twenty-first century learning" and promoted by policy documents such as the Melbourne Declaration (Ministerial Council on Education Employment Training and Youth Affairs, 2008), is proving elusive: evidence exists suggesting that merely moving into ILEs does not automatically create a change to more student-focused pedagogies (Imms, Cleveland, \& Fisher, 2016).

In the last six years, the Australian government has invested AU\$16 billion of public funding (Department of Education, Employment and Workplace Relations, 2016) to build innovative learning environments in schools in order to provide multi-modal, technology-infused and flexible learning spaces (Cleveland \& Fisher, 2014). It is becoming clear, however, that new learning environments require an understanding of new teaching methods. While building teacher performance has been well researched, little has been done specifically on pedagogy and space (Blackmore, Bateman, Loughlin, O’Mara, \& Aranda, 2011; Cleveland \& Fisher, 2014). The few existing empirical studies that address any correlation of space and student learning, and demonstrate some causality, have been small-scale studies with limited generalisability (Byers, Imms, \& Hartnell-Young, 2014).

The Plans to Pedagogy $\left(\mathrm{P}_{2} \mathrm{P}\right)$ research programme is one initiative seeking to address the shortage of research evidence to support teachers in their effective use of space. School facilities identified as ILEs commonly feature agile and flexible learning spaces, integrated technologies and purposeful furniture that can support a variety of teaching and learning modalities. The problem addressed by $\mathrm{P}_{2} \mathrm{P}$ is that the architectural designs of ILEs commonly imply a commensurate innovative use of such environments, towards meeting a pedagogical vision for student-centred learning and the development of "twentyfirst century skills" (Fullan, Langworthy, \& Barber, 2014). P2P implements a school-based strategy to assist teachers in developing the skills and knowledge required to use ILEs more effectively as a pedagogical tool. The programme also seeks to investigate the processes that schools undertake to design, build, engage and fully utilise the affordances these spaces provide. 
$\mathrm{P}_{2} \mathrm{P}$ exemplifies the concept of practitioner-led research that seeks to directly impact the quality of teaching with a view to evaluation and improvement (Campbell \& McNamara, 2009). It is a powerful means of investigating educational practices in order to reconceptualise and transform teaching practices (Campbell \& Groundwater-Smith, 2010; Somekh, 2006). Working alongside small "spatial learning teams" comprising staff in each participating school, researchers from one university's cross-disciplinary research hub engage in deep conversations with teachers and school leaders in order to: (1) identify relevant questions within each school's unique context; (2) devise school-based data collection methods; and (3) utilise the findings to implement intervention strategies or an improvement programme that address the questions raised within the umbrella of the project's key objective. The focus for this suite of projects is developing teachers' spatial competencies (Lackney, 2008), including their capacity to take advantage of the affordances (Gibson, 1977) of ILEs for contemporary teaching and learning.

Taking our lead from Kemmis's (2001) work on teachers as practitionerresearchers, we report here on the progress of $\mathrm{P}_{2} \mathrm{P}$ university-school partnerships. These partnerships were established to promote what Kemmis (2001) describes as the "self-education of teachers and school communities who want to raise and answer the questions they regard as most pressing in their own situations" (p. 17). Teachers are supported in developing the skills of research through research expertise provided by university academics (Dimmock, 2012; Swaffield \& MacBeath, 2005) to respond to the overarching research question: How can school leaders and teachers effectively engage in the design, development and use of innovative learning environments?

\section{Method}

The research programme has a duration of three years and is driven by the needs of each individual participating school. The programme works with a small "spatial learning team" (up to six members) of highly motivated teachers within each school. Each spatial learning team works under the direct supervision of an academic expert. The academic experts act as facilitators, research experts and critical friends throughout the three-year programme. These teacher-researchers contribute to the shared research question through sub-questions designed and approved by both the Responsible Researcher and the Human Ethics Advisory Group at the University.

Broadly, three phases inform the methodology and methods used at each school. Each school negotiates an individual schedule within a three-year 
structure to suit their particular needs, including sampling, data collection and data analysis strategies.

Phase 1 uses an exploratory design to investigate what is known, what gaps exist and what work needs to be done in each school. The overarching broad research question is: "What is the school's current knowledge and practice regarding ILEs?” It begins with the development of a three-year school research plan for $\mathrm{P}_{2} \mathrm{P}$. The focus depends on the needs of the school, as determined during the development of the research plan. Year 1 focuses on empowering staff to envisage good teaching and learning practices in their learning spaces.

Phase 2 focuses mostly on staff and student transitions into the spaces. The research question driving this focus is: "How can we assist teachers and students in using spatial competencies to make their good teaching and learning even better?" To do this, the Spatial Learning Team (SLT) together with its $\mathrm{P}_{2} \mathrm{P}$ academic review available strategies (Appendix 1) for their perceived "best fit" with the school's needs. The team then work with the academic's advice and expertise to develop their research skills and knowledge in the implementation of these strategies. The spatial learning team next begin to work with a selection of their school's staff to develop their skills and expertise in spatial awareness and understanding. In Year 2, the spatial learning team also begin to formally document their activities using, where possible, data that can be disseminated to the school community and, where relevant, used for Year 3 evaluation.

Phase 3 continues phase 2 activities, but with two additional foci. The first concerns evaluation. For this focus, the guiding research question is: "How can we gather evidence from the $\mathrm{P}_{2} \mathrm{P}$ project?" The second focus concerns dissemination, with the guiding question being: "How do we ensure the 'good ILE practices' become long-term practice in our school?" To meet both these goals, the Spatial Learning Team creates "outputs" in light of broader school practices. In the final year of the $\mathrm{P}_{2} \mathrm{P}$ project, the SLTs present their findings to their school community and other educational and academic audiences. A significant output of this stage is each school's participation in an academic symposium held at the university and open to academics and school staff from across the state.

Each school has developed a unique research programme relevant to its own context. However, all of the participants engage in several core learning and development events that seek to improve the teachers' research and spatial learning capacities:

- Two one-day research workshops each year at the University of Melbourne (attended by one or two representatives from each school); and - Two school visits by academic experts each year. 
The two-day workshops focus on developing specific research skills (such as qualitative, quantitative and mixed methods research) and engage participants in a range of research tools developed by the academics. These tools can be reviewed in Appendix 1.

As each school works with a research-trained academic leader, they have learned to make informed decisions about methods that suit their research questions. Table 1 gives an overview of the approaches, methods and participant numbers at each school.

Table 1

Schools' Methodological Approaches

\begin{tabular}{|c|c|c|c|}
\hline School & Research Approach & Method/s & Participant Numbers \\
\hline $\begin{array}{l}\text { Archer Girls' } \\
\text { College }\end{array}$ & Qualitative & $\begin{array}{l}\text { Pedagogical encounter } \\
\text { mapping, focus groups, } \\
\text { collaborative workshops }\end{array}$ & $\begin{array}{l}20-25 \text { teachers from } \\
\text { across the school }\end{array}$ \\
\hline $\begin{array}{l}\text { Carbine } \\
\text { College }\end{array}$ & $\begin{array}{l}\text { A quasi-experimental design } \\
\text { using mixed-methods, invol- } \\
\text { ving a non-equivalent control } \\
\text { and treatment groups com- } \\
\text { pleting a pre- and post-test, } \\
\text { where the treatment group is } \\
\text { the only group that received } \\
\text { intervention(s). }\end{array}$ & $\begin{array}{l}\text { Pre- and post-surveys of } \\
\text { teachers } \\
\text { Pre- and post-surveys of } \\
\text { students } \\
\text { Observations } \times 9 \text { per class } \\
\text { (in between } 2 \text { interven- } \\
\text { tions) }\end{array}$ & $\begin{array}{l}\text { Two team-taught } \\
\text { Year } 12 \text { classes, one } \\
\text { control and one } \\
\text { intervention }\end{array}$ \\
\hline
\end{tabular}

\begin{tabular}{|c|c|c|c|}
\hline $\begin{array}{l}\text { Coolbardi } \\
\text { Primary } \\
\text { School }\end{array}$ & $\begin{array}{l}\text { A-B-A withdrawal design. } \\
\text { Quant/qual mixed method } \\
\text { (quasi experimental) repeated } \\
\text { measures across three school } \\
\text { terms. }\end{array}$ & $\begin{array}{l}\text { Interviews } \\
\text { Observation metric (tea- } \\
\text { cher practice, LEASA tool) } \\
\text { Repeated measures survey } \\
\text { Student photo elicitation }\end{array}$ & $\begin{array}{l}\text { Grades } 3-6,5 \text { classes } \\
=\text { approx. } 135 \text { stu- } \\
\text { dents, } 5 \text { teachers. }\end{array}$ \\
\hline $\begin{array}{l}\text { Sub Zero } \\
\text { College }\end{array}$ & Qualitative & $\begin{array}{l}\text { Pedagogical encounter } \\
\text { mapping, focus groups, } \\
\text { collaborative workshops }\end{array}$ & $\begin{array}{l}20-25 \text { teachers from } \\
\text { across the school }\end{array}$ \\
\hline $\begin{array}{l}\text { Sunshine } \\
\text { School }\end{array}$ & $\begin{array}{l}\text { Repeated measures mixed } \\
\text { method design. }\end{array}$ & $\begin{array}{l}\text { Assisted repeated measu- } \\
\text { res survey. (Spatial use } \\
\text { mapping; Likert measures } \\
\text { for purpose and percepti- } \\
\text { on of learning impact) }\end{array}$ & $\begin{array}{l}\text { Years } 5,8 \text { and } 11 . \\
\text { Total of } 108 \text { partici- } \\
\text { pants. }\end{array}$ \\
\hline $\begin{array}{l}\text { Phar Lap } \\
\text { Primary } \\
\text { School }\end{array}$ & $\begin{array}{l}\text { A quasi-experimental design } \\
\text { using mixed-methods, involv- } \\
\text { ing a non-equivalent control } \\
\text { and treatment groups com- } \\
\text { pleting a pre- and post-test, } \\
\text { where the treatment group is } \\
\text { the only group that received } \\
\text { intervention(s) }\end{array}$ & $\begin{array}{l}\text { Pre and post-surveys of } \\
\text { teachers } \\
\text { Observations x } 9 \text { per class } \\
\text { (in between } 2 \text { interven- } \\
\text { tions) }\end{array}$ & $\begin{array}{l}\text { Two Year } 5 \text { classes } \\
\text { with one acting as a } \\
\text { control class }\end{array}$ \\
\hline
\end{tabular}




\begin{tabular}{|c|c|c|c|}
\hline School & Research Approach & Method/s & Participant Numbers \\
\hline $\begin{array}{l}\text { Willow } \\
\text { College }\end{array}$ & $\begin{array}{l}\text { Quasi-experimental, (control/ } \\
\text { intervention) repeated mea- } \\
\text { sures single-subject research } \\
\text { design. }\end{array}$ & $\begin{array}{l}\text { Teacher observation } \\
\text { metric (Byers tool) } \\
\text { Student repeated mea- } \\
\text { sures survey } \\
\text { Teacher PD (intervention) }\end{array}$ & $\begin{array}{l}\text { Experimental group; } \\
\text { Grade } 7 \text { (English and } \\
\text { Science) - } 4 \text { classes, } \\
4 \text { teachers } \\
\text { Control group; } \\
\text { Grade } 7 \text { (English and } \\
\text { Science) - } 4 \text { classes, } \\
4 \text { teachers } \\
\text { Total of approxi- } \\
\text { mately } 210 \text { partici- } \\
\text { pants }\end{array}$ \\
\hline $\begin{array}{l}\text { Winx } \\
\text { College }\end{array}$ & $\begin{array}{l}\text { A single-subject research de- } \\
\text { sign using mixed-methods, in } \\
\text { which subjects (teachers/ } \\
\text { students) serve as his/her } \\
\text { control }\end{array}$ & $\begin{array}{l}\text { Pre- and post-surveys of } \\
\text { teachers } \\
\text { Pre- and post-surveys of } \\
\text { students } \\
\text { Observations x } 9 \text { per class } \\
\text { (in between } 2 \text { interven- } \\
\text { tions) }\end{array}$ & $\begin{array}{l}\text { Year } 9 \text { ( } 1 \text { teacher and } \\
25 \text { students) and } \\
\text { Year } 12 \text { ( } 1 \text { teacher } \\
\text { and } 13 \text { students) } \\
\text { in two prototype } \\
\text { classrooms. }\end{array}$ \\
\hline
\end{tabular}

The eight participating schools are located across Australia and New Zealand and include schools from government, religious and independent systems, representing both primary and secondary schools. Of the eight schools, one school is beginning their second year of the $\mathrm{P}_{2} \mathrm{P}$ program, and one school completed the programme in 2019. The remaining six schools will complete their three-year programme in 2020.

\section{Findings}

The following findings have been ascertained based on qualitative reflections made by each academic expert, gathered through their work with each school over one year. These reflections are based on the experiences, opinions, thought and feelings of the academic experts throughout the research programme. It is an acknowledged part of the research process implemented by keeping reflective journals, thus demonstrating the project's focus on the research process. The findings also show how reflective journals can be used in engaging with the notion of creating transparency in the research process and in exploring the impact of critical self-reflection on research design.

Due to the small number of academics involved in the research, the reflections have been amalgamated and deidentified. It was not appropriate to include any direct quotes or attributions in the present context, as they would provide identifiable features of schools and teachers. The following sections present a broad discussion of similarities across the school contexts. Three main themes emerged as a result of the analysis of the reflections. 
While findings reveal that progress is made at a different pace within each school regardless of their stage in the three-year programme, three main themes emerged with regard to teachers as embedded practitioner-researchers: 1. The leadership of embedded research in schools;

2. The significance of teacher research to changing practice; and,

3. Challenges and changing priorities.

Each of these themes will be explored through the analysis of journal data.

\section{The leadership of embedded research in schools}

The leadership structure of the projects at each school had an impact on the success and perceived sustainability of the project. For some schools, successful leadership meant support from the senior leadership of the school or a single "champion" to lead and promote the project. In others, the spatial learning teams were seen as a group of leading teachers engaged in evaluation and improvements.

The member of the four-person spatial learning team at Phar Lap had multiple roles depending on the phase of the project, either as participants in different stages of the research or as researchers involved in collecting and analysing data. All members were, however, engaged in the dissemination of research findings, as well as in the scaling up of successful and practicable strategies throughout the school. This generally occurred throughout the year through dedicated workshops for groups of teachers, as well as at the schoolwide biannual professional development days. The success of the programme in this school is attributed to the role of the assistant principal within the spatial learning team. The assistant principal was seen as a champion who was willing to listen to new ideas (not just imposing them) and to take risks to move on from the way things have always been done. Having a positive perception of change enabled the assistant principal to harness teachers' motivation and positivity, and use it to try and help bring along those who felt less positive.

The principal at Carbine demonstrated a high level of commitment to $\mathrm{P}_{2} \mathrm{P}$ and engaged frequently with the researchers to ensure they were on track and managing data according to ethics protocols and in line with the school's overall vision. The spatial learning team have consistently communicated the value of evidence-based practice in their school, and participants in the school have conveyed the benefits of observation data in reflecting on their practices. Open communication has been a strength in this case study to date, with both the spatial learning team and participants clearly articulating the importance of 
the research in improving their practice as individuals and within their learning community.

In other schools, a strong leader combined with a committed group of teachers was seen as a factor in successful changes in the school. At Coolbardi, for instance, an adjustment in the leadership approach was needed early on in the project. The spatial learning team who initially drove the project were all senior staff; when they commenced data collection, they realised they needed support to implement the rigorous research design on top of their day-to-day school administration, and consequently released one of their teachers for one day per week to lead and manage data collection. The spatial learning team explained that this arrangement was to support the development of teacher leaders in the school, and also recognised that having one teacher leading observations provided a level of consistency that is important to the repeated-measures design of their project.

Winx has an influential institutional culture of developing practitionerled research. The model of practitioner-research as part of the $\mathrm{P}_{2} \mathrm{P}$ programme focused predominantly on one lead teacher as the practitioner-researcher who conducted the bulk of the observations, obtained survey data from teachers and students, and co-designed interventions with other teachers. The lead teacher worked closely with the university academic to ensure findings and outcomes were developed and reported back in a coherent way for the school community. The lead teacher was also the bridge to the communities of practice within the school, which led multiple projects focusing on the school priorities for the year. In this way, findings and outcomes from the programme could be fed back into the school community systematically.

Strong leadership is seen as necessary to successfully engage teachers in embedded research within schools. The role of a school leader or lead teacher in nurturing, developing and setting the culture and structures that engender practitioner-led research is well documented (Frost, 2007; Frost \& Harris, 2003; Frost \& Roberts, 2004; Hargreaves, 1996; Wilkins, 2003). A powerful way to promote such a culture is the school leader carrying out research and modelling the process of learning and enquiring (Godfrey, 2016), as in the case of Phar Lap and Coolbardi. As Godfrey (2016) argued,

the most research-engaged schools had very highly identified leadership support for engagement in (doing), and with (accessing and using) research; very strong support systems, including mentoring arrangements and training in research skills; a very high amount of research activity, involving a significant proportion of staff (and sometimes involving 
students); plentiful examples of impact within and beyond the school of the school's research efforts and a strong and well-understood research structure. (emphasis in original, p. 314).

Teacher-led development, as in the case of Coolbardi and Winx, sees research efforts as being inextricably linked with the practice of distributed leadership (Frost, 2007). Teacher-led development, often facilitated by involvement in external programmes such as $\mathrm{P}_{2} \mathrm{P}$, are seen to empower teachers and contribute to school improvement, including the spreading of good practice and initiatives generated by teachers (Muijs \& Harris, 2006). For this to be successful, however, there needs to be a culture of trust and support (ibid.) and structures that afford time, resources and space for dissemination and collaboration of research findings (Godfrey, 2016).

\section{The significance of teacher research to changing practice}

A further emerging theme from schools in the $\mathrm{P}_{2} \mathrm{P}$ programme is that teachers are changing their practice in the classroom after participating in teacher research at their school. At Carbine College, findings indicate that teachers have moved away from seeing research as something "done to them" and demonstrated feelings of empowerment from leading research and analysing the data.

Carbine has had staff challenges during the $\mathrm{P}_{2} \mathrm{P}$ project: the lead teacher and principal involved left about 6 months and 18 months, respectively, into the commencement of the programme. The university academic had been working with two teachers who were engaged in participatory action research in the first phase of the programme. This collective and self-reflective inquiry enabled the teacher-researchers to understand and improve upon the practices in which they participate and the situations in which they find themselves. In phase 2 of the programme, they were involved in practitioner-led research in an entirely different classroom, conducting interventions, collecting and analysing data, as well as conducting professional development for other teachers.

Despite the challenges faced by the school, it was gratifying to see that the role of the two teachers evolved from being "objects of inquiry" to developing a more sophisticated knowledge and understanding of the nature and purpose of research, one associated with elements of data collection, gathering feedback, collaboration and team learning, and self-reflection. One of the outcomes of the second phase of the research was a professional development video developed by the two teachers on strategies for team-teaching. The video was used as part 
of a professional development tool for the wider school community, which led to further strategies being scaled up at the level of the whole school.

At Willow, the critical issue was how teachers with proven, well-established teaching practices could be challenged to utilise the more student-centred approaches that the new ILE designs were intended to provide. The conceptual approach was one of "osmosis": developing such practices with some teachers and allowing these to permeate the teaching culture in the school over time. It was recognised that large-scale changes in something as personal as teachers' pedagogies was unlikely; instead, modelling alternative practices would allow for gradual change. Some schools, such as Archer and Winx, used communities of practices to exchange ideas and share resources. In most cases, resources were also shared through an online portal accessible to other teachers. The resources could then be used and modified in different classroom contexts.

While many teachers see professional development as "an empty exercise in compliance" (Calvert, 2016, p. 2), the teachers at Carbine acted purposefully and constructively to direct their professional growth and contribute to the growth of their colleagues. The $\mathrm{P}_{2} \mathrm{P}$ programme supported the two teachers in developing their agency for continued learning and in transforming professional learning opportunities for the whole school community relevant to their school contexts (Mewborn, 2003; Wilson \& Berne, 1999).

Roesken-Winter, Hoyles and Blömeke (2015) also argued that scaling up involves more than just a quantitative increase in the number of participating teachers. As is the case with Willow, it is also associated with qualitative changes in the responsibilities, norms and practices that bring scaling up into a dynamic and co-dependent relationship with sustainability. The recontextualisation of resources, disseminated physically or electronically, illustrates the notion of "spread" that Coburn (2003) argues is essential for scaling up education reforms.

\section{Challenges and changing priorities}

Ongoing challenges, such as time constraints and building delays, as well as changing priorities - as a result of changing leadership, for instance - was an emerging theme that impacted the $\mathrm{P}_{2} \mathrm{P}$ programme in all of the schools. While some of these challenges were similar, they affected each school differently.

While Winx valued teacher development, the school also adopted a topdown approach that was utilised to focus solely on school improvement. This meant that some teachers did not see the value of practitioner research as effecting change for social good. Furthermore, because the school engaged one teacher to lead the $\mathrm{P}_{2} \mathrm{P}$ programme within the school, many other teachers often 
acted as data collection points, rather than functioning as full participating members of the research process. Consequently, the uptake of the programme across the school has been quite variable, not only between campuses (junior, middle and high school campuses), but also across teachers and disciplines.

The research programme at Archer involved working with teachers to identify: a) valued "learning encounters", and b) effective "pedagogical routines". While perceived by some of those involved as a slow process, the collection of "learning encounter" data in the form of hand-drawn network diagrams, and the analysis of the relative value of different forms of "learning encounters" as a group process, generated significant and sometimes profound conversations about what "good" teaching and learning should look like, including across different curriculum domains. Intriguingly, teachers of seemingly unrelated subjects, such as physical education and LOTE, have found inspiration in the types of learning encounters commonly recoded and considered valued in each other's classes, and have already begun to modify their pedagogical routines in response to the research undertaken.

At Archer, there appeared to be a disconnect between teachers' expectations of research and the speed at which change should occur, on the one hand, and the academic's understanding of the need for a rigorous research methodology, on the other. The potential challenge with this disconnect is that change may be slower to enact across the school. Teachers' enthusiasm may diminish before significant changes are in place. Ensuring that the research was understood and that the findings were adopted was a challenge that was at least partially overcome through interdisciplinary learning and connections between faculties.

At Sub Zero, ongoing changes, innovations and new buildings have led to a fast-paced, frequently changing project. The project was slow to implement: term-by-term changes to the teaching programme occasionally made parts of the research design redundant, necessitating a redesign of the research protocol. However, the enthusiastic staff have maintained the steady collection of data during these changes. Similarly, the experience at Sunshine emphasised the iterative, ephemeral nature of applied design in such spaces, as well as the need for research flexibility to ensure its outputs have real value for the school. This school, however, has managed to work through the challenges of changing goals by maintaining a core group of leaders dedicated to increasing the spatial knowledge of their peers. Again, leadership appeared significant in ensuring that teacher research is successful in the school.

The ongoing changing of school contexts meant that the $\mathrm{P}_{2} \mathrm{P}$ project needed to be agile and responsive. The success of the programme could be 
attributed to the way it offered teachers and schools a principled and flexible repertoire of strategies, rather than prescribed methods and mandated resources (Goos, Bennison \& Proffitt-White, 2018). Careful consideration needed to be given to the complexity of the individual research programmes and the expectations of the school. Contingency plans were also necessary to enable quick changes and amendments to research protocols. Incorporating flexibility and agility into the research programmes also meant that research could be integrated into the teaching practices of teachers on a sustainable basis (Elliot, 2009).

\section{Implications and Conclusions}

Although not yet complete, the $\mathrm{P}_{2} \mathrm{P}$ programme has so far offered a rare opportunity to investigate practitioner-led research developed within a structured university-school collaboration that takes into account differing school contexts. It has provided some crucial insights into the supports that schools should develop to enable teachers to develop their pedagogical practice through research.

These insights include the need for teacher-focused research that meets the changing needs of teachers in the school. A flexible approach to teacherresearch is seen as a necessary aspect of successful collaboration in this project.

The $\mathrm{P}_{2} \mathrm{P}$ programme also goes some way towards addressing the call by Kemmis (2001) regarding the self-education of teachers and school communities, as well as the call by Beswick, Anderson and Hurst (2016) for researchers to devote more attention to issues of the scale and sustainability of professional learning initiatives. There are clear implications that teachers need to have time and resources accorded to them if they are to make sense of data, explore research designs and develop findings from their work. Without time and resources, the project risks failing, unless school leaders are open to reassessing the workload and resourcing of staff, as was the case at the Coolbardi Primary School. Pre-emptive planning for increased access to dedicated time, resources or staff appears to be necessary for success.

Although the study was exploratory and thus limited in the claims that can be made about teacher change, particularly in the context of the use of innovative learning environments, two points of departure provide future inquiries for practitioner-led research.

First, how do you leverage more effectively the academic-teacher relationship to enhance practitioner-led research? Teachers and school leaders need to make the most of the variety of expertise that exists with academic staff. To ensure that teachers explore what is not already known, academics 
need to engage closely with the school, their priorities and the outcomes they are seeking at critical junctures of the programme. Such knowledge could include supporting the development of specific research skills, acquiring a deeper understanding of the unique context of each school, and encouraging teacher and school leaders to drive and communicate the research across the school.

Second, an essential element of the $\mathrm{P}_{2} \mathrm{P}$ programme is the provision of structured time and support for "doing" research. How can school leaders be persuaded that this is an important investment? Particularly as challenges abound and priorities change, how can we ensure that such teacher-led research continues to thrive and be sustained over time? One way to do this is to ensure that positive outcomes of such programmes are promulgated widely, not only among practitioners and academics, but among policymakers who are responsible for education and schooling in the twenty-first century. An influential, research-informed profession would go a long way in reinvigorating the teaching profession and the transformation of educational practices.

\section{Acknowledgements}

We thank the Spatial Learning Teams at each of the eight Plans to Pedagogy schools for their contributions to this research. We also acknowledge the contributions of our industry partner.

\section{References}

Barr, A., Gillard, J., Firth, V., Scrymgour, M., Welford, R., Lomax-Smith, J., ... Constable, E. (2008). Melbourne declaration on educational goals for young Australians. ERIC.

Beswick, K., Anderson, J., \& Hurst, C. (2016). The education and development of practising teachers. In K. Makar, S. Dole, J. Visnovska, M. Goos, A. Bennison, \& K. Fry (Eds.), Research in mathematics education in Australasia 2012-2015 (pp. 329-352). Springer Science+Business Media.

Blackmore, J., Bateman, D., Loughlin, J., O'Mara, J., \& Aranda, G. (2011). Research into the connection between built learning spaces and student outcomes. Education Policy and Research Division Department of Education and Early Childhood Development, Victoria.

Byers, T., Imms, W., \& Hartnell-Young, E. (2014). Making the case for space: The effect of learning spaces on teaching and learning. Curriculum and Teaching, 29(1), 5-19.

Calvert, L. (2016). The power of teacher agency. The Learning Professional, 37(2), 51.

Campbell, A., \& Groundwater-Smith, S. (Eds.). (2010). Connecting inquiry and professional learning in education. Routledge.

Cleveland, B., \& Fisher, K. (2014). The evaluation of physical learning environments: A critical review of the literature. Learning Environments Research, 17(1), 1-28. 
Coburn, C. (2003). Rethinking scale: Moving beyond numbers to deep and lasting change.

Educational Researcher, 32(6), 3-12.

Department of Education, Employment and Workplace Relations. (2016, January 26). Building the education revolution-Primary schools for the 21st century. https:/www.anao.gov.au/work/ performance-audit/building-education-revolution-primary-schools-21st-century

Dimmock, C. A. J. (2012). Leadership, capacity building, and school improvement: Concepts, themes, and impact. Routledge.

Elliott, J. (2009, September). Lesson and learning study: A globalising form of teacher research. In Annual Conference of the British Educational Research Association, University of Manchester (pp. 2-5).

Frost, D. (2007). Practitioner research and leadership. In A. R. J. Briggs \& M. Coleman (Eds.),

Research methods in educational leadership ( $2^{\text {nd }}$ ed.). Sage.

Frost, D., \& Harris, A. (2003). Teacher leadership: Towards a research agenda. Cambridge Journal of Education, 33(3), 479-498.

Frost, D., \& Roberts, A. (2006). Teacher leadership and knowledge building: The experience of the HertsCam Network. Paper presented within the symposium, Leadership for Learning: The Cambridge Network, at the $19^{\text {th }}$ International Congress for School Effectiveness and Improvement (ICSEI). Fort Lauderdale, Florida, 3-6 January.

Frost, D., \& Roberts, J. (2004). From teacher research to teacher leadership: The case of the Hertfordshire Learning Preferences Project. Teacher Development, 82(3), 181-199.

Godfrey, D. (2016). Leadership of schools as research-led organisations in the English educational environment: Cultivating a research-engaged school culture. Educational Management Administration \& Leadership, 44(2), 301-321.

Goos, M., Bennison, A., \& Proffitt-White, R. (2018). Sustaining and scaling up research-informed professional development for mathematics teachers. Mathematics Teacher Education and Development, 20(2), 133-150.

Fullan, M., Langworthy, M., \& Barber, M. (2014). A rich seam. http://michaelfullan.ca/wp-content/ uploads/2014/01/3897.Rich_Seam_web.pdf

Gibson, J. J. (1977). The theory of affordances. Hilldale, USA, 1(2).

Harrington, M. (2013, June 26). Improving school performance. https://www.aph.gov.au/

About_Parliament/Parliamentary_Departments/Parliamentary_Library/pubs/BriefingBook44p/

SchoolPerformance

Imms, W., Cleveland, B., \& Fisher, K. (2016). Evaluating learning environments: Snapshots of emerging issues, methods and knowledge. Springer.

Kemmis, S. (2001). Educational research and evaluation: Opening communicative space [The 2000

Radford Lecture]. Australian Educational Researcher, 28(1), 1.

Lackney, J. A. (2008). Teacher environmental competence in elementary school environments.

Children Youth and Environments, 18(2), 133-159.

Mewborn, D. (2003). Teaching, teachers' knowledge, and their professional development. In J. 
Kilpatrick, W. G. Martin, \& D. Schifter (Eds.), A research companion to principles and standards for school mathematics (pp. 45-52). NCTM.

Ministerial Council on Education Employment Training and Youth Affairs. (2008). Melbourne declaration on educational goals for young Australians.

Muijs, D., \& Harris, A. (2006). Teacher led school improvement: Teacher leadership in the UK. Teaching and teacher education, 22(8), 961-972.

Roesken-Winter, B., Hoyles, C., \& Blömeke, S. (2015). Evidence-based CPD: Scaling up sustainable interventions. ZDM Mathematics Education, 47(1), 1-12. 10.1007/s11858-015-0682-7

Swaffield S., \& MacBeath J. (2006) Embedding learning how to learn in school policy: The challenge for leadership. Research Papers in Education, 21(2), 201-215.

Wilkins, R. (2003). Learning centred leadership as a function of educational empowerment.

Education Today, 53(2), 27-35.

Wilson, S. M., \& Berne, J. (1999). Teacher learning and the acquisition of professional knowledge:

An examination of research on contemporary professional development. Review of Research in

Education, 24(1), 173-209.

\section{Biographical note}

JoAnne Blannin, DEd is Senior Lecturer in Digital Transformations at Monash University, Faculty of Education. She is also honorary Fellow with the Melbourne Graduate School of Education. Her research focuses on innovations and digital pedagogies and explores the connections between innovative pedagogies and on student learning.

Marian MAhAt, PhD, is a Senior Research Fellow in the Melbourne Graduate School of Education at the University of Melbourne. Drawing on multiple fields of inquiry, her research focuses on student learning and outcomes in various educational contexts, innovative quantitative and qualitative methodologies and interdisciplinary collaboration.

Benjamin Cleveland, PhD, is a Senior Lecturer in the Faculty of Architecture, Building and Planning at the University of Melbourne, where he is Co-Director of the Learning Environments Applied Research Network (LEaRN). His research focusses on relationships between educational practice and the physical environment. 
Julia Morris, PhD, is the Course Coordinator for Visual Arts Education (Secondary) and Senior Lecturer at the School of Education, the Edith Cowan University. She is also an Honorary Research Fellow with the Melbourne Graduate School of Education. Her research focuses on participatory action research in staff and student school culture.

Wesley Imms, PhD, is an Associate Professor in the Melbourne Graduate School of Education, the University of Melbourne. His research investigates the role of schools' built environments on quality education, and evaluates the impact of space on teacher practices and student learning. 


\title{
Appendix 1: Overview of tools used in the $\mathrm{P}_{2} \mathrm{P}$ program
}

\author{
NB: the tools listed below are proprietary and the intellectual property \\ of (c) LEaRN University of Melbourne.
}

\begin{tabular}{|c|c|c|c|c|c|}
\hline LEaRN tools & Focus & Method & Analysis & Outcome & Output \\
\hline $\begin{array}{l}\text { Archipelago of } \\
\text { Possibilities }(\end{array}$ & $\begin{array}{l}\text { Allows teachers } \\
\text { to identify and } \\
\text { articulate "preferred" } \\
\text { pedagogies, steps to } \\
\text { achieve these, and } \\
\text { how learning space } \\
\text { characteristics can } \\
\text { assist. }\end{array}$ & $\begin{array}{l}\text { Design-thin- } \\
\text { king appro- } \\
\text { ach, using } \\
\text { small group, } \\
\text { facilitated } \\
\text { interactive } \\
\text { board activi- } \\
\text { ties. }\end{array}$ & $\begin{array}{l}\text { Focus group } \\
\text { discussion only; } \\
\text { cumulative } \\
\text { qualitative ana- } \\
\text { lysis possible, if } \\
\text { required. }\end{array}$ & $\begin{array}{l}\text { An agenda for } \\
\text { personal change, and } \\
\text { insights how spatial } \\
\text { affordances can } \\
\text { assist this. }\end{array}$ & $\begin{array}{l}\text { Personalised } \\
\text { pedagogy } \\
\text { development } \\
\text { artifacts. } \\
\text { "Storyboard" } \\
\text { mapping of } \\
\text { student/teacher } \\
\text { use of school's } \\
\text { new spaces }\end{array}$ \\
\hline
\end{tabular}

$\begin{array}{ll}\text { Future } & \begin{array}{l}\text { Challenges teachers } \\ \text { to consider long term } \\ \text { Curriculum }\end{array} \\ \begin{array}{ll}\text { Profiling Tool } \\ \text { in curriculum, and }\end{array} \\ \text { (FCP)(c) } & \text { how this impacts the } \\ & \text { design of new spaces }\end{array}$

$\begin{array}{ll} & \begin{array}{l}\text { Measures the impact } \\ \text { of learning environ- } \\ \text { ments on variables }\end{array} \\ \text { The LTPS@ tool } & \begin{array}{l}\text { such as student } \\ \text { engagement, teacher } \\ \text { performance, student } \\ \text { learning outcomes. }\end{array}\end{array}$

Measures the impact of learning environ-

$\begin{array}{ll}\text { Single-sub- } & \text { Inferential } \\ \text { ject research } & \text { (RM-ANOVA) } \\ \text { design } & \text { lation analysis; } \\ \text { (repeated } & \text { visual graphic } \\ \text { measures). } & \text { analysis; some } \\ \text { T tests, LME, } & \text { qualitative } \\ & \text { analysis }\end{array}$

\section{Double-inter- ning analysis,} view, checklist combined with approach.

Data to support

"future proof" design briefs, the development of long-term curriculum planning, and identification of cross-disciplinary approaches to learning.
Written report. Focus groups for "visionary" curriculum planning. and Sentience analysis. such as student learning outcomes.

Identifies existing and desired characteristics

Learn of good building

Evaluation Tool designs. Assists in the (Module 3) (c) development of an educational brief for design purposes.
Survey, focus Non-inferential groups, expert analysis, qualielicitation. tative analysis.
Statistical evidence of impact of various spatial typologies on variables such as those listed in "Focus"
Various. Graphic data analysis, written reports,

A bi-focal (site specific, and comparative analysis to "like schools") evaluation of "what works", "what needs to be changed".

Immediate feedback of data concerning teaching

Byers and learning practices

Observational in ILEs. Done across Metric(c) time, this evaluation constitutes professional development for teachers.
Repeated Non-inferenmeasurement tial analysis, tablet-based visual graphic observations analysis
Modelling of particular teachers' practices in particular learning environments. Similarly, evaluation of student learning styles, movement and behaviour.
Visual data outputs, focus and individual conversations concerning classroom practices and use of ILE affordances.

\begin{tabular}{|c|c|c|c|}
\hline $\begin{array}{l}\text { Acoustic } \\
\text { measurement } \\
\text { and treatment } \\
\text { tool } \\
\text { (under } \\
\text { negotiation, } \\
\text { Marshall Day + } \\
\text { ILETC) }\end{array}$ & $\begin{array}{l}\text { Measures reverbe- } \\
\text { ration and decibel } \\
\text { levels in specific } \\
\text { learning environments } \\
\text { and assists develop- } \\
\text { ment of remedial } \\
\text { treatments. }\end{array}$ & $\begin{array}{l}\text { Standard } \\
\text { industry }\end{array}$ & $\begin{array}{l}\text { Standard } \\
\text { industry }\end{array}$ \\
\hline
\end{tabular}

Increased teacher understanding of the Standard nature of acoustics, and how to manipulate spatial affordances to improve this. industry report specific to tested spaces. 